\title{
Mass Spectrometry Profiles Superoxide-Induced Intramolecular Disulfide in the FMN-Binding Subunit of Mitochondrial Complex I
}

\author{
Liwen Zhang, ${ }^{\mathrm{c}} \mathrm{Hua} \mathrm{Xu},{ }^{\mathrm{d}}$ Chwen-Lih Chen, ${ }^{\mathrm{a}}$ Kari B. Green-Church, ${ }^{\mathrm{b}, \mathrm{c}}$ \\ Michael A. Freitas, ${ }^{\mathrm{d}}$ and Yeong-Renn Chen $^{\mathrm{a}, \mathrm{b}}$ \\ ${ }^{a}$ Davis Heart and Lung Research Institute, Division of Cardiovascular Medicine, Department of Internal \\ Medicine, The Ohio State University, Columbus, Ohio, USA \\ ${ }^{b}$ Department of Molecular and Cellular Biochemistry, College of Medicine, The Ohio State University, \\ Columbus, Ohio, USA \\ ${ }^{\mathrm{c}}$ Campus Chemical Instrument Center, Proteomics and Mass Spectrometry Facility, The Ohio State \\ University, Columbus, Ohio, USA \\ ${ }^{\mathrm{d}}$ Department of Molecular Virology Immunology and Medical Genetics, The Ohio State University, \\ Columbus, Ohio, USA
}

Protein thiols with regulatory functions play a critical role in maintaining the homeostasis of the redox state in mitochondria. One major host of regulatory cysteines in mitochondria is Complex I, with the thiols primarily located on its $51 \mathrm{kDa}$ FMN-binding subunit. In response to oxidative stress, these thiols are expected to form intramolecular disulfide bridges as one of their oxidative post-translational modifications. Here, to test this hypothesis and gain insights into the molecular pattern of disulfide in Complex I, the isolated bovine Complex I was prepared. Superoxide $\left(\mathrm{O}_{2}^{-}\right)$is generated by Complex I under the conditions of enzyme turnover. $\mathrm{O}_{2}^{-}$-induced intramolecular disulfide formation at the $51, \mathrm{kDa}$ subunit was determined by tandem mass spectrometry and database searching, with the latter accomplished by adaptation of the in-house developed database search engine, MassMatrix [ $\mathrm{Xu}, \mathrm{H}$., et al., J. Proteome Res. 2008, 7, 138-144]. LC/MS/MS analysis of tryptic/chymotryptic digests of the $51 \mathrm{kDa}$ subunit from alkylated Complex I revealed that four specific cysteines $\left(\mathrm{C}_{125}, \mathrm{C}_{142}, \mathrm{C}_{187}\right.$, and $\mathrm{C}_{206}$ ) of the $51 \mathrm{kDa}$ subunit were involved in the formation of mixed intramolecular disulfide linkages. In all, three cysteine pairs were observed: $C_{125} / C_{142}, C_{187} / C_{206}$, and $\mathrm{C}_{142} / \mathrm{C}_{206}$. The formation of disulfide bond was subsequently inhibited by superoxide dismutase, indicating the involvement of $\mathrm{O}_{2}^{-}$. These results elucidated by mass spectrometry indicate that the residues of $\mathrm{C}_{125}, \mathrm{C}_{142}, \mathrm{C}_{187}$, and $\mathrm{C}_{206}$ are the specific regulatory cysteines of Complex I and they participate in the oxidative modification with disulfide formation under the physiological or pathophysiological conditions of oxidative stress. (J Am Soc Mass Spectrom 2008, 19, 1875-1886) (c) 2008 American Society for Mass Spectrometry

$\mathrm{M}$ itochondrial Complex I [EC 1.6.5.3. NADH: ubiquinone oxidoreductase, (NQR)] is the first energy-conserving segment of the electron transport chain (ETC) [1-3]. Purified bovine heart Complex I contains up to 45 different subunits with a total molecular mass approaching $1 \mathrm{MDa}$ [4]. With the use of chaotropic anions such as perchlorate, Complex I can be resolved into three fractions: a flavoprotein fraction (Fp), an iron sulfur protein fraction (Ip), and a hydrophobic fraction (Hp) [see Supplemental Figure 1], which can be found in the electronic version of this article. The enzyme catalyzes electron-transfer from NADH to ubiquinone coupled with the translocation of four protons across the membrane. In addition to its functions of electron-transfer and energy transduction,

Address reprint requests to Professor Yeong-Renn Chen, Davis Heart and Lung Research Institute, The Ohio State University, 473 W. 12th Ave., Suite 607, Columbus, OH 43210, USA. E-mail: yeong-renn.chen@osumc.edu the catalysis of Complex I provides the major source of oxygen free radical generation in mitochondria [5-7].

The generation of superoxide anion radical $\left(\mathrm{O}_{2}^{--}\right)$and the oxidants derived from it in mitochondria can act as a redox signal in triggering cellular events such as apoptosis, proliferation, and senescence. The redox pool in mitochondria is enriched in glutathione (GSH) with a high physiological concentration (in the $\mathrm{mM}$ range) [8]. Protein thiols are also abundant in the proteins of the mitochondrial ETC, which play a critical role in maintaining the homeostasis of the cellular redox state [9, 10]. It has been documented that Complex I is the major component of the ETC to host protein thiols, which comprise structural thiols involved in the ligands of iron sulfur clusters and the reactive/regulatory thiols, which are thought to have biological functions of antioxidant defense and redox signaling [11, 12]. The physiological roles of Complex I-derived regulatory thiols have been implicated in the regulation of the respira- 
tion, nitric oxide utilization $[13,14]$, and redox status of mitochondria [8-10].

The $51 \mathrm{kDa}$ subunit of bovine Complex I is nuclearencoded and constitutes the major component of the flavoprotein [Fp contains the enzymatic activity of NADH dehydrogenase (NDH) and can be isolated as a three-subunit subcomplex indicated in the Supplemental Figure 1] of Complex I. This subunit contains the NADH-binding site, the primary electron acceptor $\mathrm{FMN}$, and the $4 \mathrm{~F}-4 \mathrm{~S}$ cluster (N3 center). The $51 \mathrm{kDa}$ subunit is also one of the major components to host the reactive/regulatory thiols of Complex I [11, 12, 15, 16]. The bovine protein has 12 cysteine residues, but only five of them are conserved in bacterial enzyme. Four of the conserved cysteines form a typical $4 \mathrm{Fe}-4 \mathrm{~S}$ cluster motif, $\mathrm{C}_{379}-\mathrm{X} 2-\mathrm{C}_{382}-\mathrm{X} 2-\mathrm{C}_{385}-\mathrm{X} 39-\mathrm{C}_{425}$ ( $\mathrm{X}$ represents amino acid residue) near the $\mathrm{C}$-terminal domain. The other conserved cysteine is located at position $206[1,3]$.

It has been demonstrated that the biological relevance of $\mathrm{C}_{206}$ of the $51 \mathrm{kDa}$ subunit in the oxidative damage of Complex I is to play the unique role of reactive thiol, based on the evidence of immunospin trapping with 5,5-dimethyl pyrroline $\mathrm{N}$-oxide (DMPO) and mass spectrometry [15]. With a proteomic approach, $\mathrm{C}_{206}$ of the $51 \mathrm{kDa}$ subunit was further determined to be involved in the redox modification of protein S-glutathiolation [16]. An X-ray crystal structure of the hydrophilic domain of respiratory Complex I from bacterial enzyme of Thermus thermophilius indicates that this conserved cysteine $\left(\mathrm{Cys}_{182}\right.$ in Thermus thermophilius) is only $6 \AA$ from the FMN, which is consistent with the role of $\mathrm{C}_{206}$ as a redox-sensitive thiol and FMNs serving as a source of $\mathrm{O}_{2}^{--}$[17].

The residues of $\mathrm{C}_{125}, \mathrm{C}_{142}, \mathrm{C}_{187}, \mathrm{C}_{238}, \mathrm{C}_{255}, \mathrm{C}_{286}$, and $\mathrm{C}_{332}$ are the seven remaining cysteinyl residues; these are not conserved in the bacterial enzyme, but they are conserved in mammalian enzymes. Protein disulfide formation is the other important oxidative post-translational modification for the regulatory thiols of $51 \mathrm{kDa}$ subunit of Complex I, and could be induced by oxidative stress. To date, this issue has never been clarified, and its molecular pattern remains unclear.

Due to the nature of complexity in the structure of mitochondrial Complex I, elucidation of the disulfide profile in the Complex I is a challenge. Recently, a mass spectrometric approach has become popular for studying the structure and post-translational modification of mammalian Complex I [2, 4, 18-20]. With the development of MassMatrix program and its applications [2123], it is feasible to solve its molecular pattern of disulfide linkage through mass spectrometric analysis. This study was undertaken to address the fundamental questions regarding the molecular pattern of disulfide bond formation in the FMN-binding subunit from the Complex I under the conditions of oxidative stress. Bovine Complex I was prepared under reducing conditions in the presence of dithiothreitol (DTT) and subsequently subjected to $\mathrm{O}_{2}^{--}$generation under the conditions of enzyme turnover in the presence of NADH and $\mathrm{Q}_{1}$. Complex I was thus exposed to the physiolog- ically relevant conditions of oxidative stress. The approaches of proteomics, mass spectrometry, and database search with MassMatrix were then employed to identify the specific cysteine residues involved in the formation of the disulfide linkage from the $51 \mathrm{kDa}$ subunit of Complex I. The biological implication of this study is also discussed.

\section{Experimental}

\section{Preparations of Mitochondrial Complex I}

Bovine heart mitochondrial Complex I was prepared according to the published method with modifications as follows [24]. Submitochondrial particles (SMP) were prepared as described and used as the starting material [25], beginning with $2.5 \mathrm{lb}$ of trimmed bovine hearts with the fat and connective tissues removed. The SMP preparation was suspended in $50 \mathrm{mM}$ Tris-Cl buffer, pH 8.0, containing $1 \mathrm{mM}$ histidine and $0.66 \mathrm{M}$ sucrose (TSH), and then subjected to precipitation with $\mathrm{KCl}$ in the presence of deoxycholate $(0.3 \mathrm{mg} / \mathrm{mg}$ protein). The supernatant thus obtained was mixed with an appropriate amount of cold water to precipitate trace amounts of cytochrome $c$ oxidase, and then dialyzed against $10 \mathrm{mM}$ Tris- $\mathrm{Cl}$, pH 8.0, containing $1 \mathrm{mM}$ EDTA for $6 \mathrm{~h}$ with one change of buffer. The dialysate was subjected to centrifugation $(96,000 \times g$ for $75 \mathrm{~min})$. The pellet containing Complexes I, II, and III was homogenized in TSH buffer, and then subjected to repeated ammonium acetate fractionation in the presence of deoxycholate $(0.5 \mathrm{mg} / \mathrm{mg}$ protein). Complex I was finally resolved (39\% saturation of ammonium sulfate) and separated using ammonium sulfate precipitation (35.9\% saturation) in the presence of potassium cholate (0.4 mg/mg protein).

\section{Analytical Methods}

Optical spectra were measured on a Shimadzu (Columbia, MD) 2401 UV/VIS recording spectrophotometer. The protein concentration of Complex I was determined by the Lowry method using BSA as standard. The concentration of $Q_{1}$ was determined by absorbance spectra from $\mathrm{NaBH}_{4}$ reduction using a millimolar extinction coefficient $\varepsilon_{(275 \mathrm{~nm}-290 \mathrm{~nm})}=12.25 \mathrm{mM}^{-1} \mathrm{~cm}^{-1}$ [26]. The enzyme activity of Complex I was assayed by measuring rotenone-sensitive NADH oxidation by $\mathrm{Q}_{1}$. An appropriate amount of Complex I was added to an assay mixture $(1 \mathrm{~mL})$ containing $20 \mathrm{mM}$ potassium phosphate buffer, $\mathrm{pH} 8.0,2 \mathrm{mM} \mathrm{NaN}_{3}, 0.1 \mathrm{mM} \mathrm{Q}_{1}$, and $0.15 \mathrm{mM}$ NADH as developed by Hatefi [27]. The Complex I activity was determined by measuring the decrease in absorbance at $340 \mathrm{~nm}$. The specific activity of Complex I was calculated using a molar extinction coefficient $\varepsilon_{340 \mathrm{~nm}}=6.22 \mathrm{mM}^{-1} \mathrm{~cm}^{-1}$. The purified Complex I exhibited a specific activity of $\sim 1.0 \mu \mathrm{mol}$ $\mathrm{NADH}$ oxidized $\mathrm{min}^{-1} \mathrm{mg}^{-1}$. 


\section{Electron Paramagnetic Resonance Measurements}

EPR measurements were performed on a Bruker EMX spectrometer operating at $9.863 \mathrm{GHz}$ with $100 \mathrm{kHz}$ modulation frequency at room temperature. The reaction mixture was transferred to a $50 \mu \mathrm{L}$ capillary, which was then positioned in the high sensitivity (HS) cavity (Bruker Instrument, Billerica, MA). The sample was scanned using the following parameters: center field, $3510 \mathrm{G}$; sweep width, $140 \mathrm{G}$; power, $19.97 \mathrm{~mW}$; receiver gain, $2 \times 10^{5}$; modulation amplitude, $1 \mathrm{G}$; time of conversion, $81.92 \mathrm{~ms}$; time constant, $163.84 \mathrm{~ms}$; number of scans, five. The spectral simulations were performed using the WinSim program developed at NIEHS by Duling [28]. The hyperfine coupling constants used to simulate the spin adduct of DEPMPO/OOH were Isomer $1: a^{\mathrm{N}}=13.14 \mathrm{G}, a_{\beta}^{\mathrm{H}}=11.04 \mathrm{G}, a_{\gamma}^{\mathrm{H}}=0.96 \mathrm{G}$, $a^{\mathrm{P}}=49.96 \mathrm{G}(79.8 \%$ relative concentration); Isomer 2 : $a^{\mathrm{N}}=13.18 \mathrm{G}, a_{\beta}^{\mathrm{H}}=12.59 \mathrm{G}, a_{\gamma}^{\mathrm{H}}=3.46 \mathrm{G}, a^{\mathrm{P}}=48.2 \mathrm{G}$ (20.2\% relative concentration).

\section{Disulfide Formation Mediated by $\mathrm{O}_{2}^{--}$Generation of Complex I}

Purified Complex I (5 mg/mL) was reduced with DTT $(1 \mathrm{mM})$ to ensure that it was in the fully cysteine sulfhydryl form. Excess DTT was removed by dialysis against TSH buffer $\left(600 \times\right.$ volumes) at $4{ }^{\circ} \mathrm{C}$ for $90 \mathrm{~min}$. Complex I (DTT-treated, $0.2 \mathrm{mg} / \mathrm{mL}$ in PBS) was incubated with NADH $(1 \mathrm{mM})$ and $\mathrm{Q}_{1}(0.4 \mathrm{mM})$ at room temperature for $1 \mathrm{~h}$ in the absence or presence of Mn-SOD (1 unit/ $\mu \mathrm{L}$ ). The reaction mixture was then subjected to alkylation with iodoacetamide before in-gel proteolytic digestion.

\section{Alkylation of Complex I with Iodoacetamide}

The sample of Complex I was subjected to alkylation with iodoacetamide $\left(\mathrm{ICH}_{2} \mathrm{CONH}_{2}\right)$ to block free thiols of protein. Complex I $(0.2 \mathrm{mg} / \mathrm{mL})$ in reaction mixture was incubated with iodoacetamide $(1 \mathrm{mM})$ at room temperature. After $1 \mathrm{~h}$ incubation, more iodoacetamide was added to the final concentration of $1.5 \mathrm{mM}$ and the mixture was incubated at $4{ }^{\circ} \mathrm{C}$ for $8 \mathrm{~h}$. The protein band of the $51 \mathrm{kDa}$ subunit in the SDS-PAGE of Complex I overlapped with the bands from the subunits of $49 \mathrm{kDa}$ (Ip) and ND5 (Hp) [16]. Therefore, to facilitate the identification of disulfide bond(s) in the $51 \mathrm{kDa}$ subunit, the Fp fraction of alkylated Complex I was partially purified by a procedure involving ethanol ( $9 \% \mathrm{vol} / \mathrm{vol})$ extraction at $40{ }^{\circ} \mathrm{C}$ that removed the $\mathrm{Hp}$ fraction and most of the Ip fraction of Complex I [15]. This partially purified Fp fraction containing multiple subunits was subjected to SDS-PAGE. The resulting gel band of 51 $\mathrm{kDa}$ was subjected to in-gel digestion with trypsin or chymotrypsin or both, and followed by LC/MS/MS analysis.
Trypsin, Chymotrypsin, and Trypsin/Chymotrypsin Digestion

The protein separated by SDS-PAGE gels was digested with sequencing grade trypsin from Promega (Madison, WI) or sequencing grade chymotrypsin from Roche (Indianapolis, IN) using the Montage In-Gel Digestion Kit from Millipore (Bedford, MA) following the manufacturer's recommended protocols. Briefly, bands were trimmed as close as possible to minimize background polyacrylamide material. Gel pieces were then washed in $50 \%$ methanol/5\% acetic acid for $1 \mathrm{~h}$. The washing step was repeated once before gel pieces were dehydrated in acetonitrile. The gel bands were washed again with cycles of acetonitrile and ammonium bicarbonate $(100 \mathrm{mM})$ in $5 \mathrm{~min}$ increments. After the gels were dried in a speed vac, the protease was driven into the gel pieces by re-hydrating them in $50 \mu \mathrm{L}$ of sequencing grade modified trypsin, chymotrypsin, or a combination of both at $20 \mu \mathrm{g} / \mathrm{mL}$ in $50 \mathrm{mM}$ ammonium bicarbonate for $10 \mathrm{~min}$. An aliquot of $20 \mu \mathrm{L}$ of $50 \mathrm{mM}$ ammonium bicarbonate was added to the gel bands and the mixture was incubated at room temperature overnight. The peptides were extracted from the polyacrylamide with $50 \%$ acetonitrile and $5 \%$ formic acid several times and pooled together. The extracted pools were concentrated in a speed vac to $\sim 25 \mu \mathrm{L}$.

\section{Capillary-Liquid Chromatography-Nanospray Tandem Mass Spectrometry (Nano-LC/MS/MS)}

Nano LC/MS/MS was performed on a Thermo Finnigan LTQ mass spectrometer equipped with a nanospray source operated in positive ion mode. The LC system was an UltiMate Plus system from LC-Packings A Dionex Co (Sunnyvale, CA) with a Famos autosampler and Switchos column switcher. Solvent A was water containing $50 \mathrm{mM}$ acetic acid and Solvent B was acetonitrile. Five microliters of each sample were first injected onto the trapping column (LC-Packings A Dionex Co.), and washed with $50 \mathrm{mM}$ acetic acid. The injector port was switched to inject and the peptides were eluted off the trap onto the column. A $5-\mathrm{cm} 75-\mu \mathrm{m}$-i.d. ProteoPep II C18 column (New Objective, Inc. Woburn, MA) packed directly in the nanospray tip was used for chromatographic separations. Peptides were eluted directly off the column into the LTQ system using a gradient of $2 \%$ to $80 \%$ B over $30 \mathrm{~min}$, with a flow rate of $300 \mathrm{~nL} / \mathrm{min}$. A total run time was $58 \mathrm{~min}$. The MS/MS was acquired according to standard conditions established in the laboratory. Briefly, a nanospray source operated with a spray voltage of $3 \mathrm{kV}$ and a capillary temperature of $200{ }^{\circ} \mathrm{C}$ is used. The scan sequence of the mass spectrometer was based on the TopTen method; the analysis was programmed for a full scan recorded between 350 and $2000 \mathrm{Da}$, and a MS/MS scan to generate product ion spectra in consecutive instrument scans of the 10 most abundant peaks in the spectrum. The CID fragmentation energy was set to $35 \%$. To 
exclude multiple MS/MS, dynamic exclusion is enabled with a repeat count of $30 \mathrm{~s}$, exclusion duration of $350 \mathrm{~s}$, a low mass width of 0.5 , and high mass width of $1.50 \mathrm{Da}$.

Sequence information from the MS/MS data were processed using the Mascot 2.0 active perl script with standard data processing parameters to form a peaklist (mgf file). Database searching was performed against NCBInr database using the Mascot 2.0 (Matrix Science, Boston, MA) for the identification of carbamoylmethylated cysteines. The mass accuracy of the precursor ions was set to $1.5 \mathrm{Da}$ to accommodate accidental selection of the ${ }^{13} \mathrm{C}$ ion and the fragment mass accuracy was set to $0.5 \mathrm{Da}$. The number of missed cleavages permitted in the search was 2 for both tryptic and chymotryptic digestions. The considered modifications (variable) were methionine oxidation and cysteine carbamoylmethylation. The data were later searched by MassMatrix, a program designed for the identification of disulfide bonds [21]. The mass accuracy of the precursor ions was set to 2.0 Da and the fragment mass accuracy was set to $0.8 \mathrm{Da}$ as default value in MassMatrix search to include all possible disulfide bonds linkage. Possible hits from Mascot and MassMatrix were manually verified.

\section{Results}

DEPMPO Spin Trapping of $\mathrm{O}_{2}^{--}$Generated by Complex I under the Conditions of Enzyme Turnover

The isolated Complex I showed an electron-transfer activity in catalyzing rotenone-sensitive NADH oxidation by ubiquinone $\left(Q_{1}\right)$ at room temperature. Due to the low oxygen tension $\left(P_{\mathrm{O}_{2}}=1-2 \mathrm{~mm} \mathrm{Hg}\right)$ and high concentration of GSH in mitochondria [29], it is reasonable to assume that most of the protein thiols (except the structural thiols for the ligands of iron-sulfur clusters) are present as cysteine sulfhydryls in vivo. The isolated Complex I was reduced with DTT $(1 \mathrm{mM})$ to ensure that it is in the fully cysteine sulfhydryl form. Excess DTT was removed by dialysis against TSH buffer at $4{ }^{\circ} \mathrm{C}$ for $90 \mathrm{~min}$.

Mitochondrial Complex I-mediated $\mathrm{O}_{2}^{--}$production can be induced under the conditions of enzyme turnover in the presence of NADH and ubiquinone-1 $\left(Q_{1}\right)$. The generated $\mathrm{O}_{2}^{--}$can be detected and measured by EPR spin-trapping. Complex $\mathrm{I}$ in the fully cysteine sulfhydryl form $(0.2 \mathrm{mg} / \mathrm{mL})$ was incubated with the nitrone spin trap, 5-diethoxylphosphoryl-5-methyl-1pyrroline $N$-oxide (DEPMPO, $20 \mathrm{mM}$ ) in PBS. The reaction was initiated by the addition of NADH (1 mM) and $\mathrm{Q}_{1}(0.4 \mathrm{mM})$. A multi-line EPR spectrum was acquired that was characteristic of DEPMPO/OOH (Figure 1a, solid line) based on hyperfine coupling constants [Isomer 1: $a^{\mathrm{N}}=13.14 \mathrm{G}, a^{\mathrm{H}}{ }_{\beta}=11.04 \mathrm{G}, a_{\gamma}^{\mathrm{H}}=$ $0.96 \mathrm{G}, a^{\mathrm{P}}=49.96 \mathrm{G}(80 \%$ relative concentration); Isomer $2: a^{\mathrm{N}}=13.18 \mathrm{G}, a_{\beta}^{\mathrm{H}}=12.59 \mathrm{G}, a_{\gamma}^{\mathrm{H}}=3.46 \mathrm{G}$, $a^{\mathrm{P}}=48.2 \mathrm{G}(20 \%$ relative concentration) $]$ obtained from the computer simulation (Figure 1a, dashed line) [15]. That the DEPMPO/ OOH adduct arose from the trap-
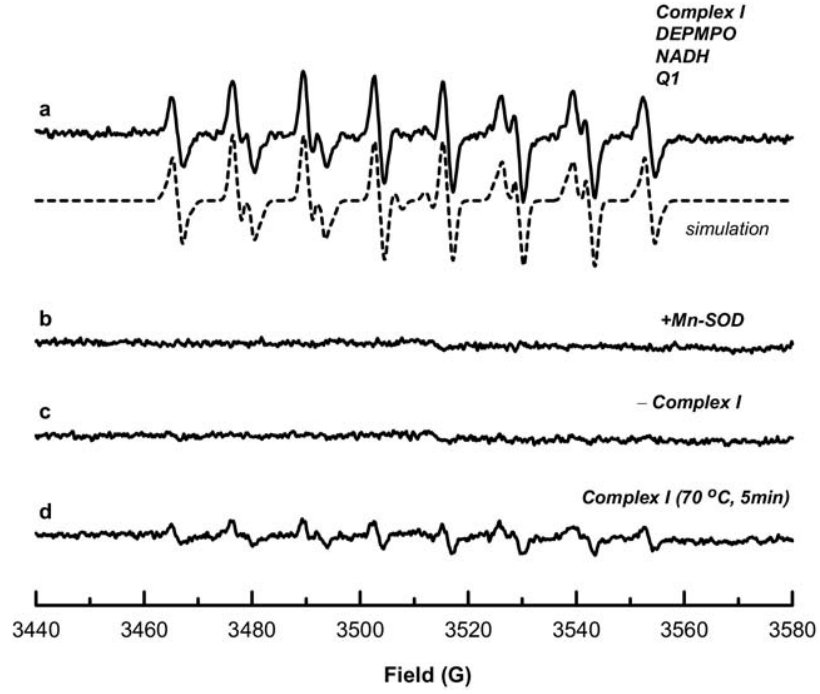

Figure 1. EPR spin trapping of $\mathrm{O}_{2}^{--}$generated from Complex I in the presence of DEPMPO under the conditions of enzyme turnover. (a) The computer simulation (dashed line) superimposed on the experimental spectrum (solid line) obtained using Complex I (0.2 $\mathrm{mg} / \mathrm{mL}$, reduced by DTT), DEMPO (20 mM), DTPA (1 mM), NADH $(1 \mathrm{mM})$, and $\mathrm{Q}_{1}(0.4 \mathrm{mM})$ in PBS. The experimental spectrum was recorded after signal averaging five scans at room temperature. The absolute basal activity of Complex I-mediated $\mathrm{O}_{2}^{-}$generation is $0.87 \mathrm{nmol} \mathrm{O}_{2}^{--}$production/min/mg NQR using 4-hydroxy-2,2,6,6-tetramethylpiperidinyloxy (TEMPOL) as a standard for spin quantitation. (b) The same as (a), except that Mn-SOD $(1 \mathrm{U} / \mu \mathrm{L})$ was added to the mixture before the reaction was initiated by NADH. (c) The same as (a), except that the enzyme was heated at $70{ }^{\circ} \mathrm{C}$ for 5 min before EPR measurement. (d) The same as (a), except that the enzyme was omitted from the system.

ping of $\mathrm{O}_{2}^{--}$was confirmed by the addition of $\mathrm{Mn}$ containing superoxide dismutase (Mn-SOD, 1 unit/ $\mu \mathrm{L}$ ) to the reaction system (Figure $1 \mathrm{~b}$ ); upon its addition the adduct formation was completely prevented. In the absence of Complex I, no DEPMPO/OOH was detected (Figure 1c). When Complex I was replaced with heat-denatured $\left(70{ }^{\circ} \mathrm{C}\right.$ for $5 \mathrm{~min}$ ) Complex I, the formation of DEPMPO/OOH was inhibited (Figure 1d). These results indicate the enzymatic dependence of the DEPMPO adduct formation.

\section{Mediation of Disulfide Formation in the $51 \mathrm{kDa}$ Subunit of Complex I by Oxidative Stress}

In the absence of spin trap, $\mathrm{O}_{2}^{--}$mediated by Complex I was expected to induce oxidative modification with disulfide bond formation at the $51 \mathrm{kDa}$ subunit since FMN-binding Fp is involved in the electron leakage for $\mathrm{O}_{2}^{--}$production [15]. To test this hypothesis, oxidative attack of Complex I was initiated by incubation of enzyme $(0.2 \mathrm{mg} / \mathrm{mL}$ in PBS) with $\mathrm{NADH}(1 \mathrm{mM})$ and $\mathrm{Q}_{1}(0.4 \mathrm{mM})$ at room-temperature for $1 \mathrm{~h}$. The amount of $\mathrm{O}_{2}^{--}$generation was $\sim 52 \mathrm{nmol} / \mathrm{mg}$ Complex I (or 0.87 $\mathrm{nmol} / \mathrm{min} / \mathrm{mg}$ Complex I) during the enzyme turnover. The reaction mixture was subjected to alkylation with iodoacetamide. To investigate the disulfide forma- 
tion in the $51 \mathrm{kDa}$ subunit, iodoacetamide, an alkylation reagent that specifically reacts with free cysteines present in the Complex I, was used to block free cysteines through carbamoylmethylation (addition of $-\mathrm{CH}_{2} \mathrm{CONH}_{2}$ ) as described in the Experimental section. The alkylation with iodoacetamide potentially prevents the disulfide formation caused by disproportionation such as thiol-disulfide exchange. The alkylated $51 \mathrm{kDa}$ subunit was then separated from other components in Complex I (lane 1 of Figure 2) using 9\% ethanol extraction at $40{ }^{\circ} \mathrm{C}$ and SDS-PAGE gel indicated in the Figure 2 (lane 2), and the protein band of $51 \mathrm{kDa}$ was subjected to in-gel digestion with trypsin and chymotrypsin or a combination of trypsin/chymotrypsin under nonreducing conditions. The sequence of the digested peptide was analyzed by LC/MS/MS and the results were searched with Mascot (Matrix Science) and MassMatrix [21] to identify disulfide formation.

As shown in Figure 3, 12 of 12 cysteine residues were identified with more than $90 \%$ of the protein sequence coverage by MS/MS. The MS/MS data were further searched with MassMatrix to identify any disulfide bonds present in this protein. MassMatrix is a database search engine available in house for identification of peptide sequences from tandem mass spectrometry data [21]. The program was adapted such that it would

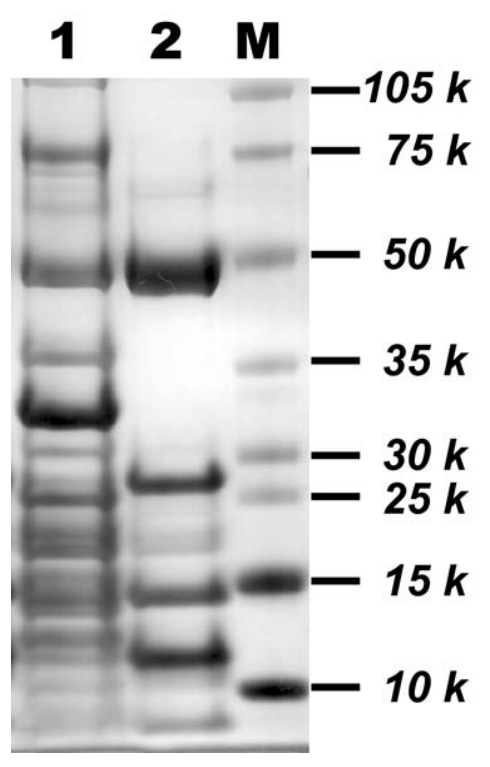

Figure 2. Preparation of the crude NADH dehydrogenase (NDH, Fp subcomplex) from carbamoylmethylated Complex I. Complex I was alkylated with iodoacetamide according to the procedure described in the Experimental section; $100 \%$ ethanol was added to a final concentration of $9 \%(\mathrm{vol} / \mathrm{vol})$, and the mixture was incubated at $40{ }^{\circ} \mathrm{C}$ for $10 \mathrm{~min}$. The sample was then chilled in an ice-salt water bath for $10 \mathrm{~min}$ and subjected to centrifugation at $25,000 \mathrm{rpm}$ for $30 \mathrm{~min}$. The supernatant containing crude NDH was collected and concentrated with Centricon 30. Carbamoylmethylated Complex I and crude NDH were subjected to SDS-PAGE using $4 \%-12 \%$ Bis-Tris polyacrylamide gel. Lane 1, Carbamoylmethylated Complex I (30 $\mu \mathrm{g})$; lane 2, crude NDH preparation $(15 \mu \mathrm{g})$ from carbamoylmethylated Complex I. $\mathrm{M}$ represents a molecular weight marker.
01 MLAARRLIGG SLPARVSVRF SGDTTAPKKT SFGSLKDEDR IFTNLYGRHD 51 WRLKGAOSRG DWYKTKEILI KGPDWILGEV KTSGLRGRGG AGFPTGLKWS 101 FMNKPSDGRP KYLVVNADEG EPGTCKDREI IRHDPHKLVE GCLVGGRAMG 151 ARAAYIYIRG EFYNEASNLQ VAIREAYEAG LIGKNACGSG YDFDVFVVRG 201 AGAYICGEET ALIESIEGKQ GKPRLKPPFP ADVGVFG̈CPT TVANVETVAV 251 SPTICRRGGA WFASFGRERN SGTKLFNISG HVNNPCTVEE EMSVPLKELI 301 EKHAGGVTGG WDNLLAVIPG GSSTPLIPKS VCETVLMDFD ALIQAQTGLG 351 TAAVIVMDRS TDIVKAIARL IEFYKHESCG QCTPCREGVD WMNKVMARFV 401 RGDARPAEID SLWEISKQIE GHTICALGDG AAWPVQGLIR HFRPELEERM 451 QQFAQQHQAR QAAF

Figure 3. Amino acid sequence of the precursor of the Complex I-51 kDa FMN-binding subunit. The regions labeled with bold represent the amino acid residues identified with LC/MS/MS. The underlined regions are the sequence motif of $4 \mathrm{Fe}-4 \mathrm{~S}$ binding (aa 379-425). The cysteines involved in the $4 \mathrm{Fe}-4 \mathrm{~S}$ binding are $\mathrm{C}_{379}, \mathrm{C}_{382}, \mathrm{C}_{385}$, and $\mathrm{C}_{425}$. The cysteinyl residues involved in disulfide linkage are highlighted with gray and they are $\mathrm{C}_{125}, \mathrm{C}_{142}$, $\mathrm{C}_{187}$, and $\mathrm{C}_{206}$. The region labeled with a dotted underline is the $\mathrm{N}$-terminal extension (aa 1-20), which acts as an import sequence and does not exist in the mature protein.

generate tandem mass spectrometry spectra for all putative peptides containing intramolecular disulfide bonds. The program was then able to score matches between the tandem mass spectra and the disulfide linked peptides. This approach required no derivatization of the sample provided efforts were undertaken to reduce disulfide exchange. The search results were all manually examined. The results showed that four cysteines, $C_{125}, C_{142}, C_{187}$, and $C_{206}$, were involved in the formation of disulfide bonds, but in a random pattern. Overall, three pairs of disulfide bonds were observed in tryptic digestion: $\mathrm{C}_{125} / \mathrm{C}_{142}, \mathrm{C}_{142} / \mathrm{C}_{206}$, and $\mathrm{C}_{187} / \mathrm{C}_{206}$ (Figure 4, Figure 5, and Figure 6, vide infra) and two pairs of disulfide bonds were observed in tryptic/ chymotryptic digestion: $C_{142} / C_{206}$ and $C_{187} / C_{206}$ (vide infra). The results are summarized in the Table 1.

\section{Identification of Disulfide Bonds in the $51 \mathrm{kDa}$ Subunit of Complex I by LC/MS/MS}

Involvement of $\mathrm{C}_{125}$ and $\mathrm{C}_{142}$ in the Disulfide Bond Formation. When MS/MS was performed on the triply charged $\left[(\mathrm{M}+3 \mathrm{H})^{3+}\right]$ peak at $\mathrm{m} / \mathrm{z} 956.22^{3+}, b$ ions (b2A-b7A) from peptide chain 112-128 (Chain A) and $y$ ions $(y 3 B-y 5 B)$ from peptide chain 138-146 (Chain B) were observed as indicated in the Figure 4 . In addition, a series of ions with loss of part of the sequence was also observed, including loss of YL (M - YL, $m / z$ 1295.44 $\left.{ }^{2+}\right)$, YLV $\left(\mathrm{M}-\mathrm{YLV}, m / z 1245.89^{2+}\right)$, YLVV $(\mathrm{M}-\mathrm{YLVV}, \mathrm{m} / \mathrm{z}$ $\left.1196.36^{2+}\right)$, YLVVN (M - YLVVN, $\left.m / z 1139.25^{2+}\right)$, YLVVNA $\left(\mathrm{M}-\right.$ YLVVNA, $\left.m / z \quad 1103.85^{2+}\right), \quad$ YLVVNAD $\left(\mathrm{M}-\mathrm{YLVVNAD}, \mathrm{m} / \mathrm{z} 1046.32^{2+}\right)$, YLVVNADE (M - YLVVNADE, $m / z 981.84^{2+}$ ), and YLVVNADEGE (M - YLVVNADEGE, $m / z 888.78^{2+}$ ) from Chain A (aa 112-128); these ions subsequently disappeared under reducing conditions in the presence of DTT or $\beta$-mercaptoethanol $(\beta-\mathrm{ME})$. Therefore, they were identified to be peptide fragments containing the disulfide linkage between $\mathrm{C}_{126}$ and $\mathrm{C}_{142}$, and the species with $m / z 956.22^{3+}$ consisted of two fragments, peptide 112128 and peptide 138-146, connected through the disulfide bond between $\mathrm{C}_{125}$ and $\mathrm{C}_{142}$. Detailed MS/MS assignment is also listed in the Supplemental Table 1. 

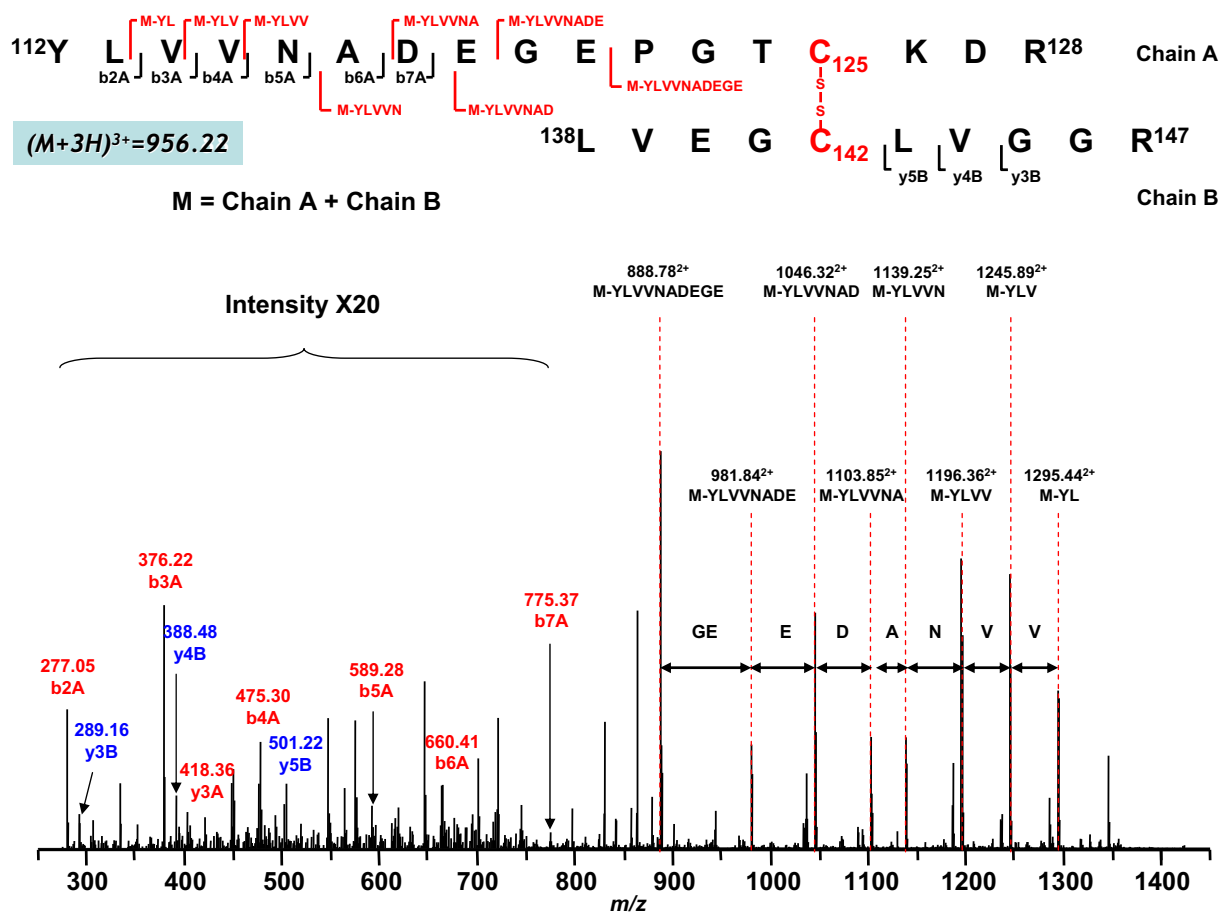

Figure 4. Disulfide bond linkage between $C_{125}$ and $C_{142}$ as determined by MS/MS spectrum of tryptic digests of the $51 \mathrm{kDa}$ subunit of Complex I. Complex I was exposed to the conditions of superoxide production, and then alkylated by iodoacetamide as described in the Materials and Methods section. Crude NADH dehydrogenase (NDH) was prepared from Complex I as described in the published procedure [16]. The obtained crude NDH was subjected to SDS-PAGE under nonreducing conditions. The gel band of the $51 \mathrm{kDa}$ polypeptide was subjected to in-gel digestion before LC/MS/MS as described in the Materials and Methods section. Chain A and Chain B represent peptides containing aa 112-128 and aa 138-147, respectively. A disulfide bond linking Chain A with Chain $\mathrm{B}$ is indicated in red. The sequence-specific ions are labeled as bnA $(n=2-7)$ for Chain $\mathrm{A}$, and ynB $(n=3-5)$ for Chain B on the spectrum. M indicates Chain A plus Chain B.

Involvement of $\mathrm{C}_{187}$ and $\mathrm{C}_{206}$ in the Disulfide Bond Formation. Figure 5 shows the MS/MS spectrum indicating disulfide bond linkage between peptide 185-199 (Chain A) and 200-219 (Chain B) through $\mathrm{C}_{187}$ and $\mathrm{C}_{206}$. As illustrated in Figure 5, MS/MS was performed on a triply charged peak with an $m / z$ of $1219.95^{3+}$. Several $b$ ions $(b 5 B, b 6 B)$ and $y$ ions $(y 4 B-y 13 B)$ from peptide chain 200-219 (Chain B) were observed, as well as $y$ ions $(y 3 A-y 9 A, y 11 A, y 12 A)$ from peptide chain 185-199 (Chain A). Fragments containing the partial sequence of the whole branched peptide $(\mathrm{M}=$ Chain $\mathrm{A}+$ Chain $\mathrm{B})$ were also observed as the cleavage occurred at the C-terminus from both chains, including the cleavage at $\mathrm{R}$ through GSGYDFDVFVVR from peptide chain 200219 (Figure 5, shown in the upper panel) and GK through GEETALIESIEGK from peptide chain 185-199 (the same spectrum of Figure 5 shown in the lower panel). The molecular ions of these fragments subsequently disappeared in the presence of thiol-containing reducing agents such as DTT or $\beta$-ME, thus supporting a disulfide linkage between $\mathrm{C}_{187}$ and $\mathrm{C}_{206}$. Detailed MS/MS assignment is also listed in Supplemental Table 2.

The molecular pattern of disulfide linkage between $\mathrm{C}_{187}$ and $\mathrm{C}_{206}$ was further evidenced by the detection of a doubly protonated ion $(\mathrm{M}+2 \mathrm{H})^{2+}$ with $\mathrm{m} / \mathrm{z} 1101.20^{2+}$ obtained from trypsin/chymotrypsin combined digests (Table 1). MS/MS was performed on this doubly charged peak. Several $y$ ions $(y 3 B-y 13 B)$ and two $b$ ions (b5B and b6B) from Chain B (aa 200-219) were observed (indicated in Supplemental Figure 2). In addition, a series of ions with loss of part of the sequence from Chain A (aa 185-196) was also observed, including loss of $\mathrm{F}\left(\mathrm{M}-\mathrm{F}, \mathrm{m} / z 1569.38^{2+}\right)$, VF $\left(\mathrm{M}-\mathrm{VF}, \mathrm{m} / z 1520.20^{2+}\right)$, DVF (M - DVF, $\left.m / z 1462.30^{2+}\right)$, FDVF (M - FDVF, $m / z$ $\left.1388.59^{2+}\right)$, DFDVF (M - DFDVF, $\left.m / z 1331.07^{2+}\right)$, GYDFDVF (M - GYDFDVF, $\left.m / z 1221.35^{2+}\right)$, and GSGYDFDVF (M - GSGYDFDVF, $m / z 1149.11^{2+}$ ) (indicated in Supplemental Figure 2). These ions were not detected by MS under reducing conditions.

Involvement of $C_{142}$ and $C_{206}$ in the Disulfide Bond Formation. As shown in Figure 6, when MS/MS was performed on a triply charged species at an $\mathrm{m} / \mathrm{z}$ of $1004.50^{3+}$, MS/MS fragments were observed at 289.16, 388.23, and 501.42, which can be assigned as $y 3 A, y 4 A$ and $y 5 A$ from peptide 138-147 (Chain A). Similarly, a second series of fragment ions was assigned as $y 3 B-y 13 B$ from peptide 200-219 (Chain B). In addition, a series of ions with loss of part of the sequence from Chain B (aa 200-219) was also observed, 


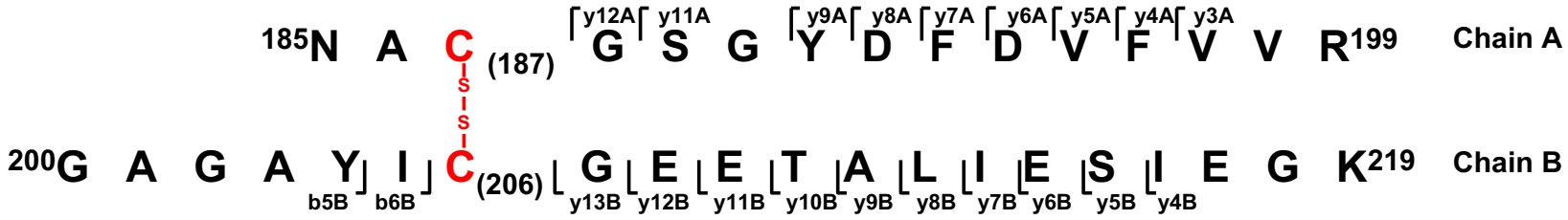

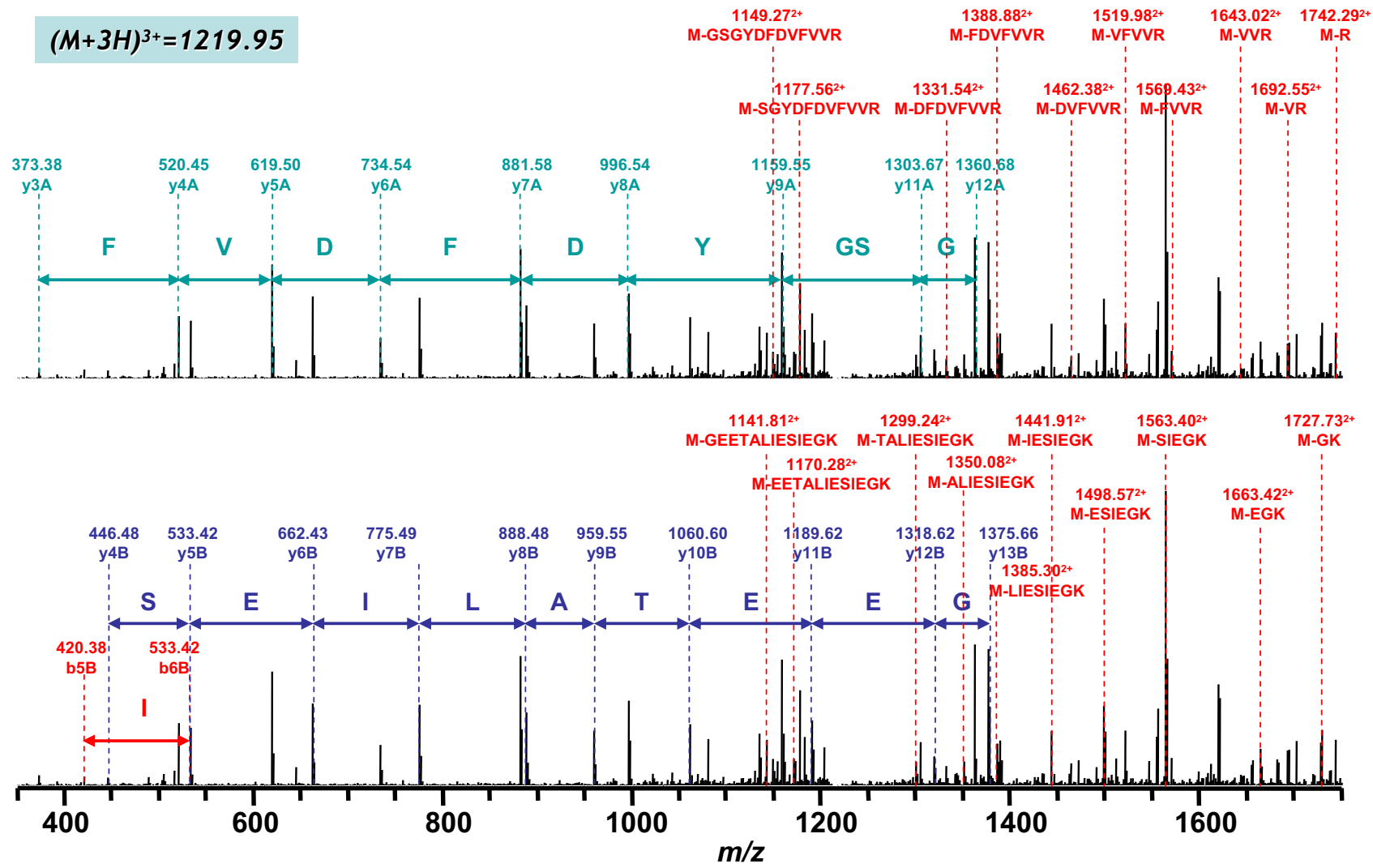

Figure 5. Disulfide bond linkage between $C_{187}$ and $C_{206}$ as determined by MS/MS spectrum of tryptic digests of the $51 \mathrm{kDa}$ subunit of Complex I. Chain A and Chain B represent peptides containing aa 185-199 and aa 200-219, respectively. A disulfide bond linking Chain A with Chain B is indicated in red. The sequence-specific ions are labeled as ynA $(n=3-9$ and 11-12) for Chain $\mathrm{A}$ and ynB $(n=$ $4-13)$, bnB $(n=5-6)$ for Chain B on the spectrum. M indicates Chain A plus Chain B. Note that the same spectrum is shown in upper and lower panels.

including loss of GK (M - GK, $m / z$ 1404.41 $\left.{ }^{2+}\right)$, EGK (M EGK, $\left.m / z 1339.84^{2+}\right)$, SIEGK $(\mathrm{M}-$ SIEGK, $\mathrm{m} / \mathrm{z}$ $\left.1239.89^{2+}\right)$, ESIEGK (M - ESIEGK, $\left.m / z 1175.38^{2+}\right)$, IESIEGK $\left(\mathrm{M}-\right.$ IESIEGK, $\left.m / z 1118.80^{2+}\right)$, TALIESIEGK $\left(\mathrm{M}-\right.$ TALIESIEGK, $\left.\mathrm{m} / \mathrm{z} 976.21^{2+}\right)$, ETALIESIEGK $(\mathrm{M}-$ ETALIESIEGK, $\mathrm{m} / \mathrm{z} 911.68^{2+}$ ), EETALIESIEGK (M EETALIESIEGK, $m / z 847.12^{2+}$ ), GAGAY (M - GAGAY, $\mathrm{m} / \mathrm{z} 1296.43^{2+}$ ), and GAGAYI (M - GAGAYI, $\mathrm{m} / \mathrm{z}$ $1239.89^{2+}$ ) (indicated in the Figure 6). This information, combined with the determined molecular weight, suggested that this species consisted of peptide fragments 138-147 and 200-219 linked together through a disulfide bond between $\mathrm{C}_{142}$ and $\mathrm{C}_{206}$. Detailed MS/MS assignment is also listed in Supplemental Table 3.

The molecular pattern of disulfide bond formation involved in the $C_{142}$ and $C_{206}$ was further evidenced by detecting a triply protonated ion with $\mathrm{m} / z 703.28^{3+}$ obtained from proteolytic digestion with trypsin/ chymotrypsin combination. MS/MS was performed on this triply charged peak. Several $y$ ions $(y 2 B-y 9 B)$ from Chain B (aa 205-219) were observed (indicated in Supplemental Figure 3) In addition, a series of ions with loss of part of the sequence from Chain B was also observed, including loss of $\mathrm{K}[\mathrm{M}-\mathrm{K}, \mathrm{m} / \mathrm{z}$ $980.40^{2+} ; \mathrm{M}=$ Chain A (aa 139-143) + Chain B (aa 205-219)], GK (M - GK, $\left.m / z 951.90^{2+}\right)$, IEGK (M IEGK, $\left.m / z 830.98^{2+}\right)$, SIEGK (M - SIEGK, $\mathrm{m} / \mathrm{z}$ $\left.787.38^{2+}\right)$, ESIEGK (M - ESIEGK, $\left.\mathrm{m} / \mathrm{z} 722.69^{2+}\right)$, IESIEGK $\left(\mathrm{M}-\right.$ IESIEGK, $\left.\mathrm{m} / \mathrm{z} \quad 666.34^{2+}\right)$, and LIESIEGK $\left(\mathrm{M}\right.$ - LIESIEGK, $\left.m / z 609.60^{2+}\right)$ indicated in the Supplemental Figure 3. Likewise, these ions were not detected by MS under reducing conditions in the presence of $\beta$-ME. 

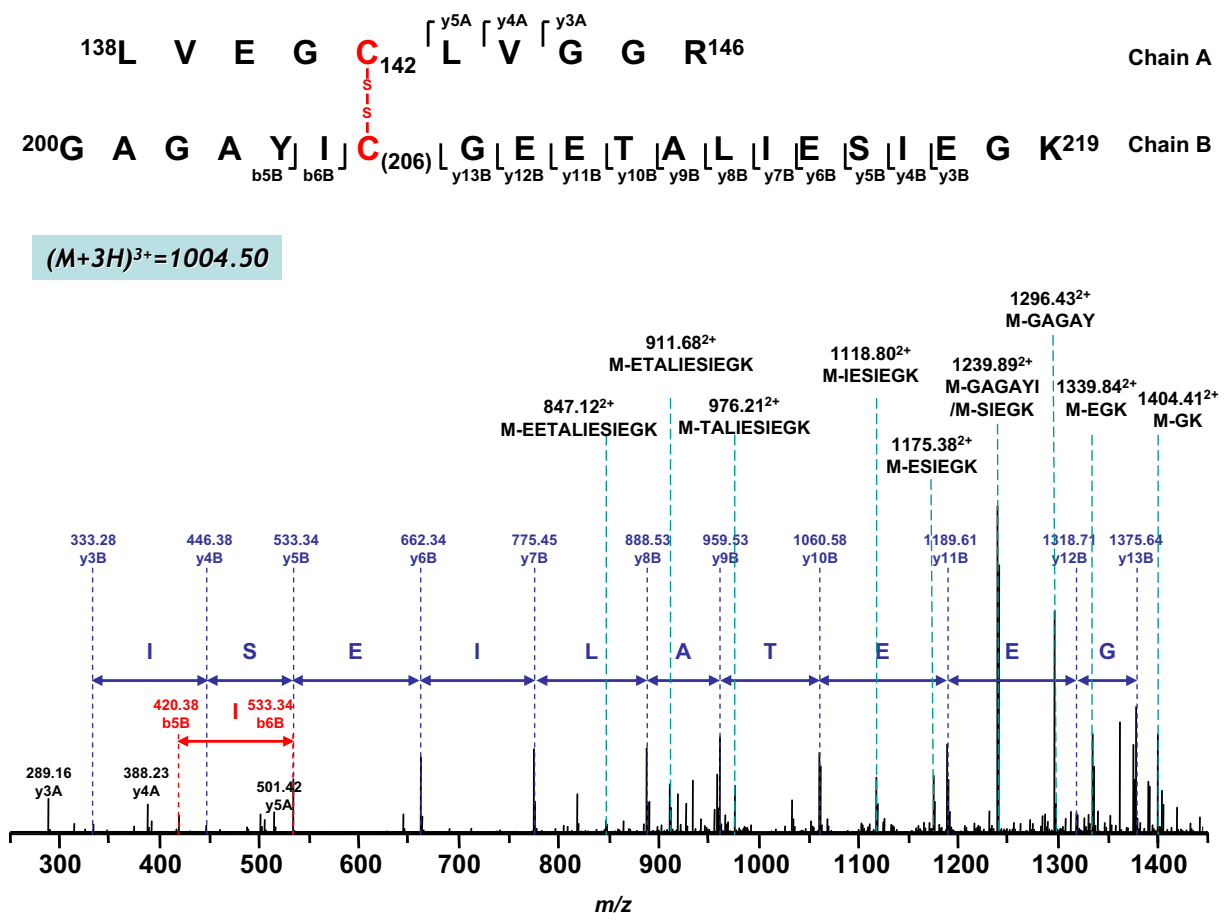

Figure 6. Disulfide bond linkage between $\mathrm{C}_{142}$ and $\mathrm{C}_{206}$ as determined by MS/MS spectrum of doubly protonated molecular ion obtained from tryptic digests of the $51 \mathrm{kDa}$ subunit of Complex I. Chain A and Chain B represent peptides containing aa 138-147 and aa 200-21, respectively. A disulfide bond linking Chain $\mathrm{A}$ with Chain $\mathrm{B}$ is indicated in red. The sequence-specific ions are labeled as ynA $(n=3-5)$ for Chain A, and ynB $(n=3-13)$, bnB $(n=5-6)$ for Chain B on the spectrum.

\section{Identification of Carbamoylmethylated Cysteine of Complex I-51 kDa by LC/MS/MS}

The sequences of peptides with carbamoylmethylated cysteines were further verified manually. As indicated in Table 2, all cysteines of the alkylated $51 \mathrm{kDa}$ subunit were observed to be carbamoylmethylated, including the residues $\left(\mathrm{C}_{379}, \mathrm{C}_{382}, \mathrm{C}_{385}\right.$, and $\left.\mathrm{C}_{425}\right)$ involved in the ligands of the $4 \mathrm{Fe}-4 \mathrm{~S}$ cluster N3 center. Presumably, the structure of the $4 \mathrm{Fe}-4 \mathrm{~S}$ coordinates may suffer partial destruction under the conditions of oxidative stress and extensive alkylation (incubation with $1.5 \mathrm{mM}$ iodoacetamide for $8 \mathrm{~h}$ ).

It is worth noting that alkylation of three $4 \mathrm{Fe}-4 \mathrm{~S}$ ligands, $\mathrm{C}_{379}, \mathrm{C}_{382}$, and $\mathrm{C}_{385}$, was not observed in the MS spectra under modest conditions (incubation with 1.0 $\mathrm{mM}$ iodoacetamide for $1 \mathrm{~h}$ ). Presumably, these three structural thiols involved in $4 \mathrm{Fe}-4 \mathrm{~S}$ binding are buried inside the Complex I and structurally protected, which can only be alkylated under vigorous conditions.

Iodine, a potential oxidative agent, could be produced through drastic conditions of iodoacetamide alkylation. However, the detection of $\mathrm{O}_{2}^{--}$-induced specific disulfide formation was not affected by iodoacetamide pretreatment. That is, we have detected the same molecular pattern of disulfide linkage without alkylation of Complex I, thus eliminating the possibility of artifactual disulfide bond formation caused by iodine.

Table 1. Detection of oxygen free radical(s)-mediated disulfide bond formation in the $51 \mathrm{kDa}$ polypeptide of complex I by LC/MS/MS

\begin{tabular}{|c|c|c|c|}
\hline Enzyme & $\mathrm{m} / \mathrm{z}$ & Linked peptide & SS pair \\
\hline \multirow[t]{3}{*}{ Trypsin } & $1004.50^{3+}$ & $\begin{array}{l}{ }^{138} \text { LVEGC }_{(142)} \text { LVGGR }^{146} \\
{ }^{200} \mathrm{GAGAYIC}_{(206)} \text { GEETALIESIEGK }^{219}\end{array}$ & $\mathrm{C}_{142} / \mathrm{C}_{206}$ \\
\hline & $956.22^{3+}$ & $\begin{array}{l}{ }^{112} \text { YLVVNADEGEPGTC }_{(125)} \text { KDR }^{128} \\
{ }^{138} \text { LVEGC }_{(142)} \text { LVGGR }^{147}\end{array}$ & $\mathrm{C}_{125} / \mathrm{C}_{142}$ \\
\hline & $1219.95^{3+}$ & $\begin{array}{l}{ }^{185} \mathrm{NAC}_{(187)} \mathrm{GSG}_{(14)} \text { SFDVFVVR }^{199} \\
{ }^{200} \mathrm{GAGAYIC}_{(206)} \text { GEETALIESIEGK }^{219}\end{array}$ & $\mathrm{C}_{187} / \mathrm{C}_{206}$ \\
\hline \multicolumn{4}{|c|}{ Trypsin + chymotrypsin } \\
\hline & $1101.20^{3+}$ & $\begin{array}{l}{ }^{185} \text { NAC }_{(187)} \text { GSGYDFDVF }^{196} \\
{ }^{200} \mathrm{GAGAYIC}_{(206)} \text { GEETALIESIEGK }^{219}\end{array}$ & $\mathrm{C}_{187 /} \mathrm{C}_{206}$ \\
\hline & $703.28^{3+}$ & $\begin{array}{l}{ }^{139} \mathrm{VEGC}_{(142)} \mathrm{L}^{143} \\
{ }^{205} \mathrm{C}_{(206)} \mathrm{GEETALIESIEGK}^{219}\end{array}$ & $\mathrm{C}_{142 /} \mathrm{C}_{206}$ \\
\hline
\end{tabular}


Table 2. Detected fragments containing carbamoyl methylated cysteines from the $51 \mathrm{kDa}$ subunit of complex I subjected to oxidative attack by $\mathrm{O}_{2}^{-}$

\begin{tabular}{|c|c|c|c|}
\hline Detected $\mathrm{m} / \mathrm{z}$ & Enzyme & Fragment & Cys detected \\
\hline $826.53^{2+}$ & Trypsin & 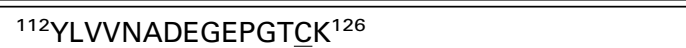 & $\mathrm{C}_{125}$ \\
\hline $826.65^{2+}$ & Tryp/chymo & ${ }^{112}$ YLVVNADEGEPGTCK ${ }^{126}$ & $\mathrm{C}_{125}$ \\
\hline $962.17^{2+} / 641.71^{3+}$ & Trypsin & ${ }^{112}$ YLVVNADEGEPGTCKDR $^{128}$ & $\mathrm{C}_{125}$ \\
\hline $745.12^{2+}$ & Tryp/chymo & ${ }^{113}$ YLVVNADEGEPGTCK ${ }^{126}$ & $\mathrm{C}_{125}$ \\
\hline $587.74^{3+}$ & Tryp/chymo & ${ }^{113}$ LVVNADEGEPGTCKDR $^{128}$ & $\mathrm{C}_{125}$ \\
\hline $530.58^{2+}$ & Tryspin & ${ }^{138}$ LVEGCLVGGR $^{147}$ & $\mathrm{C}_{142}$ \\
\hline $530.53^{2+}$ & Tryp/chymo & ${ }^{138}$ LVEGCLVGGR $^{147}$ & $\mathrm{C}_{142}$ \\
\hline $1010.38^{2+}$ & Chymo & ${ }^{178}$ EAGLIGKNACGSGY DFDVF ${ }^{196}$ & $\mathrm{C}_{187}$ \\
\hline $1351.33^{1+}$ & Tryp/chymo & ${ }^{185}$ NACGSGYDFDVF $^{196}$ & $\mathrm{C}_{187}$ \\
\hline $853.60^{2+}$ & Trypsin & ${ }^{185}$ NACGSGYDFDVFVVR $^{199}$ & $\mathrm{C}_{187}$ \\
\hline $1034.70^{2+} / 690.14^{3+}$ & Trypsin & ${ }^{200} \mathrm{GAGAYICGEETALIESIEGK}{ }^{219}$ & $\mathrm{C}_{206}$ \\
\hline $1034.80^{2+}$ & Tryp/chymo & ${ }^{200}$ GAGAYICGGEETALIESIEGK ${ }^{219}$ & $\mathrm{C}_{206}$ \\
\hline $824.76^{2+}$ & Tryp/chymo & ${ }^{205}$ ICGEETALIESIEGK ${ }^{219}$ & $\mathrm{C}_{206}^{206}$ \\
\hline $1133.87^{2+}$ & Trypsin & ${ }^{225}$ LKPPFPADVGVFGCPTTVANVETVAVSPTIC $\mathrm{R}^{256}$ & $\mathrm{C}_{238}$ and $\mathrm{C}_{255}$ \\
\hline $1066.78^{2+}$ & Tryp/chymo & ${ }^{237}$ GCPTTVANVETVAVSPTIC ${ }^{256}$ & $\mathrm{C}_{238}$ and $\mathrm{C}_{255}$ \\
\hline $1307.58^{2+} / 872.07^{3+}$ & Trypsin & ${ }^{275}$ LFNISGHVNNPCTVEEEMSVPLKE ${ }^{297}$ & $\mathrm{C}_{286}$ \\
\hline $1121.68^{2+}$ & Chymo & ${ }^{277}$ NISGHVNNPCTTVEEEM $(\mathrm{Ox})$ SVPL $^{296}$ & $\mathrm{C}_{286}$ \\
\hline $1121.69^{2+}$ & Tryp/chymo & ${ }^{277} \mathrm{NISGHVNNP}{ }_{\text {TVEEEM }}(\mathrm{Ox}) \mathrm{SVPL}^{296}$ & $\mathrm{C}_{286}^{286}$ \\
\hline $1185.77^{2+} / 791.02^{3+}$ & Tryp/chymo & ${ }^{277}$ NISGHVNNPCETVEEEM $\left(\mathrm{Ox}_{\mathrm{X})}\right.$ SVPLK $^{297}$ & $\mathrm{C}_{286}$ \\
\hline $573.44^{2+}$ & Chymo & ${ }^{327}$ IPKSVCETVL $^{336}$ & $\mathrm{C}_{332}$ \\
\hline $928.04^{2+}$ & Chymo & ${ }^{327}$ IPKSVCETVLM $_{(\mathrm{Ox})}$ DFDAL $^{342}$ & $\mathrm{C}_{332}$ \\
\hline $1086.08^{3+}$ & Trypsin & ${ }^{330}$ SVCETVLMDFDALIQAOTGLGTAAVIVM $_{(\mathrm{Ox})} \mathrm{DR}^{359}$ & $\mathrm{C}_{332}$ \\
\hline $465.04^{3+}$ & Trypsin & ${ }^{376} \mathrm{HES} \underline{C}$ GQCTPCR ${ }^{386}$ & $\mathrm{C}_{379}, \mathrm{C}_{382}$ and $\mathrm{C}_{385}$ \\
\hline $1096.87^{2+}$ & Trypsin & ${ }^{418}$ QIEGHTICALGDGAAWPVOGL ${ }^{438}$ & $\mathrm{C}_{425}$ \\
\hline $1231.87^{2+} / 821.14^{3+}$ & Trypsin & ${ }^{418}$ QIEGHTICAALGDGAAWPVQGLIR ${ }^{440}$ & $\mathrm{C}_{425}$ \\
\hline $822.04^{3+}$ & Tryp/chymo & ${ }^{418}$ QIEGHTICALGDGAAWPVOGLIR ${ }^{440}$ & $\mathrm{C}_{425}$ \\
\hline
\end{tabular}

It should be noted that the residues $\left(\mathrm{C}_{125}, \mathrm{C}_{142}, \mathrm{C}_{187}\right.$, and $\mathrm{C}_{206}$ ) involved in disulfide linkage were also observed to be carbamoylmethylated (Table 2), suggesting that both cysteine sulfhydryl (or free thiol form) and cysteine disulfide (induced by $\mathrm{O}_{2}^{-}$) are present in residues $\mathrm{C}_{125}, \mathrm{C}_{142}, \mathrm{C}_{187}$, and $\mathrm{C}_{206}$ of the $51 \mathrm{kDa}$ subunit of Complex I. Therefore, these four specific cysteines only partially participated in the disulfide linkage and the detected disulfide formation induced by oxidative stress was not uniform.

\section{Involvement of $\mathrm{O}_{2}^{--}$in the Disulfide Bond Formation}

When Mn-SOD (1 unit $/ \mu \mathrm{L}$ ) was included in the reaction system containing Complex I/NADH $/ \mathrm{Q}_{1}$, no disulfide linkage was detected in the $51 \mathrm{kDa}$ subunit of Complex I by LC/MS/MS, suggesting the involvement of oxidative attack by $\mathrm{O}_{2}^{--} /$or $\mathrm{O}_{2}^{--}$-derived oxidants.

In the control experiment, Complex I (DTT-treated) was incubated at room temperature for $1 \mathrm{~h}$ in the absence of $\mathrm{NADH}$ and $\mathrm{Q}_{1}$ before alkylation with iodoacetamide. LC/MS/MS analysis of tryptic/or chymotryptic peptides of $51 \mathrm{Da}$ revealed no disulfide formation. These results illustrate that the formation of the $51 \mathrm{kDa}$-derived disulfide bond is physiologically relevant and is involved in the biological event of oxidative stress.

\section{Discussion}

Advantage of the Mass Spectrometry Coupled with MassMatrix Program in the Detection of Protein Disulfide Linkages

The investigation of disulfide bonds is critical for understanding the biological properties and function of a protein but has not always been an easy task for researchers. X-ray crystallography and NMR are excellent tools for studying the 3D structure of proteins, thus providing information regarding disulfide linkages [30-33]. However, large amounts of well purified protein with good solubility or the proper size crystal are required for these two methods, respectively [34]. Furthermore, some proteins must interact with other proteins to accomplish their biological function. It is usually difficult to separate one protein from other associated components in a solution phase. Some proteins containing regulatory thiols can only form disulfide linkages under conditions of oxidative stress (the $51 \mathrm{kDa}$ FMN-binding subunit of Complex I in this study). The disulfide bonds thus formed are not necessarily uniform, and are unlikely to be well characterized by X-ray crystallography.

Mass spectrometry has been widely used to identify disulfide bonds [35-44]. Proteins can be investigated either in solution phase [34, 37, 42] or from a gel [40,45]. Since protease is used to decrease the size of the protein/ peptide in MS analysis, large-sized proteins can also be 
analyzed. It has been demonstrated that disulfide bridge patterns can be identified by partial reduction followed by MS analysis [42, 43, 46, 47]. However, when a protein is highly disulfide bond bridged, this approach requires multiple reduction and separation steps for the complete mapping of protein disulfide bonds. In addition, this method fails when multiple disulfide bonds show similar reduction kinetics [46].

Tandem MS followed by proteolytic digestion under nonreducing conditions is another approach to characterizing the disulfide pattern of a given protein [34, 37, $38,40,45,48-51]$. With appropriate protease(s) employed, the pattern of disulfide linkages can be identified in a single run. However, most of the data are manually analyzed, which is time-consuming and labor-intensive. This factor makes data analysis extremely difficult, especially for proteins with unknown disulfide linkages such as the $51 \mathrm{kDa}$ FMN-binding subunit of Complex I in this study. Also, it tends to miss some information when the sample contains large number of cysteines with multiple mixed intra-molecular disulfide bonds in the protein.

In this study, the modified database search program MassMatrix was used to provide the candidate list of disulfide linked peptides, which greatly simplified data analysis and reduced the rate of false negative matches [21]. With the aid of MassMatrix, we were able to completely and accurately identify oxygen free radicalinduced disulfide bonds in the FMN-binding subunit of Complex I. Four out of 12 cysteine residues were identified as involved in the formation of three disulfide bonds: $C_{125} / C_{142}, C_{187} / C_{206}$, and $C_{142} / C_{206}$ in the Complex I under the conditions of oxidative stress. None of the identified cysteines is associated with the cysteinyl ligands of the $4 \mathrm{Fe}-4 \mathrm{~S}$ cluster (N3 center).

\section{Biological Implications}

Mitochondrial thiols are composed of protein thiols and the GSH/GSSG pool. The proteins of the mitochondrial electron transport chain are rich in protein thiols $[9,10]$. An analysis of rat liver mitochondria has shown them to contain $65-70 \mathrm{nmol}$ of thiols per $\mathrm{mg}$ of protein. Excluding the structural thiols involved in the ligands of metal centers, $\sim 20-25 \mathrm{nmol}$ of thiols per $\mathrm{mg}$ of protein are exposed. The content of GSH/GSSG for isolated liver mitochondria is $3-5 \mathrm{nmol}$ per $\mathrm{mg}$ of protein $[9,10]$. Therefore, protein thiols play a critical role in controlling the redox state of mitochondria.

Mitochondrial Complex I is the major component of the ETC to host protein thiols, which comprise structural thiols involved in the ligands of iron sulfur clusters and the reactive/regulatory thiols, which are thought to have biological functions of antioxidant defense and redox signaling [11, 12]. The physiological roles of Complex I-derived regulatory thiols have been associated with the regulation of respiration, nitric oxide utilization [13, 14], redox status of mitochondria [8-10], and redox modifications such as S-glutathiolation [16] and protein thiyl radical formation [15].

The current studies identified four cysteine residues, $\mathrm{C}_{125}, \mathrm{C}_{142}, \mathrm{C}_{187}$, and $\mathrm{C}_{206}$, that are involved in the mixed intramolecular disulfide linkages induced by oxidative stress. However, the formed intramolecular disulfide is not uniform since the evidence obtained from alkylation with iodoacetamide clearly indicated that free thiols of residues $C_{125}, C_{142}, C_{187}$, and $C_{206}$ are also present in the Complex I that was exposed to oxidative challenge (Figure 1 and Table 1). We did not detect any disulfide bridge involvement for the other four cysteine residues, $C_{238}, C_{255}, C_{286}$, and $C_{332}$, based on the data analysis obtained from LC/MS/MS and MassMatrix database searching. Therefore, it can be suggested that the residues of $\mathrm{C}_{125}, \mathrm{C}_{142}, \mathrm{C}_{187}$, and $\mathrm{C}_{206}$ function as the regulatory thiols in the FMN-binding subunit of Complex I. They may contribute to the homeostasis of thiol redox in mitochondria. In previous studies, we have identified $\mathrm{C}_{206}$ to be the reactive cysteine susceptible to oxidative attack of oxygen free radical(s), forming a specific protein thiyl radical [15]. In a separate study, $\mathrm{C}_{206}$ was also identified as involved in the redox event of protein S-glutathiolation when Complex I was exposed to oxidized glutathione, GSSG [16]. In the present studies, $\mathrm{C}_{206}$ and $\mathrm{C}_{187}$ /or $\mathrm{C}_{142}$ were formed disulfide linkage induced by oxidative attack (Figure 5 and Figure 6). Two additional cysteine residues, $\mathrm{C}_{125}$ and $\mathrm{C}_{142}$, were further identified as participants in the redox event of disulfide formation due to oxidative stress (Figure 4).

The milieu of the mitochondrial matrix is almost anoxic (oxygen tension, $\mathrm{Po}_{2}=1-2 \mathrm{~mm} \mathrm{Hg}$ ) in the presence of the GSH/GSSG pool under normal physiological conditions [29]. Analysis of redox compartmentation indicates that the relative redox states from most reductive to most oxidative are as follows: mitochondria $>$ nuclei $>$ endoplasmic reticulum $>$ extracellular space [29]. Thus, it is expected that low oxygen tension in the mitochondrial environment should facilitate the free thiol state for most regulatory cysteines; and that mitochondrial thiols are the targets of oxygen free radical(s) and are vulnerable to oxidative stress. Presumably, the formation of disulfide linkages is a mechanism of antioxidant defense adopted by mitochondrial proteins in response to oxidative stress. This conclusion is strongly supported by the data from EPR spin trapping (Figure 1) and analysis of disulfide formation by exposure of Complex I to oxidative stress (Figures 4-6).

The homology model (aa: 38-445 in bovine protein and shown in Supplemental Figure 4) is built via MODELLER ver. 8 [52], using the structure of the hydrophilic domain of respiratory Complex I of Thermus thermophilius (PDB ID 2FUG) as a template with a sequence identity of $46 \%$. This model is not likely to logically explain the detected disulfide pattern (Figures 4-6) based on the crystal structure since the measured distances of the pairs including $\mathrm{C}_{206} / \mathrm{C}_{187}(34.7 \AA)$, $\mathrm{C}_{206} / \mathrm{C}_{142}(19.5 \AA)$, and $\mathrm{C}_{125} / \mathrm{C}_{142}(20.5 \AA)$ are longer 
than a reasonable distance $(<6.4 \AA$ [53]) for disulfide formation. Therefore, it is suggested that protein may suffer an oxygen free radical-induced conformational change in solution to facilitate disulfide formation. Specifically, cysteine-related reversible oxidative alternation such as protein thiyl radical formation or cysteine sufenic/sufinic acids may contribute to this change. The presumed oxidative alteration does not include irreversible cysteine sulfonation, which would not lead to disulfide formation. It should not be ruled out that other oxidative modifications, such as methionine oxidation, may induce conformational change before the formation of the disulfide bonds. If this were the case, one would expect that methionine oxidation should be extensive enough to bring specific cysteines into close enough contact for disulfide bond formation.

\section{Conclusions}

The use of LC/MS/MS coupled with MassMatrix program facilitates solving the molecular pattern of disulfide formation induced by oxidant stress. Specifically, we have successfully employed this technique to a complicated enzymatic system. Importantly, the approach can be potentially applied to other mitochondrial proteins containing redox thiols in vitro and in vivo. Furthermore, the intramolecular disulfide pattern elucidated here provides a useful concept for understanding the fundamental question of how Complex I utilizes its specific regulatory thiols to address situations of oxidative stress caused by oxygen free radical attack. Clearly, the major role of specific disulfide formation is to regulate the redox signal of oxygen free radical or its derived oxidant. Recognition of this molecular event is important in understanding the fundamental basis of regulatory cysteines in Complex I.

\section{Acknowledgments}

The authors thank Mr. Alexander Yeh (Davis Heart and Lung Research Institute) for assistance in the preparation of Complex I, Dr. Chenglong Li (Division of Medicinal Chemistry and Pharmacognosy, College of Pharmacy) for building the homology model of Complex I-51 kDa, and Mr. Richard Sessler from the Mass Spectrometry and Proteomics Facility for assistance with the mass spectrometric experiments. This work was supported by RO1 grant from the National Institutes of Health [(HL083237, to Y-R C)]. MAF was supported by NIH CA107106 and CA101956, Leukemia and Lymphoma Society (SCOR 708006), and the V Foundation/American Association for Cancer Research Translational Cancer Research grant.

\section{References}

1. Hirst, J.; Carroll, J.; Fearnley, I. M.; Shannon, R. J.; Walker, J. E. The Nuclear Encoded Subunits of Complex I from Bovine Heart Mitochondria. Biochim. Biophys. Acta. 2003, 1604, 135-150.

2. Carroll, J.; Fearnley, I. M.; Shannon, R. J.; Hirst, J.; Walker, J. E. Analysis of the Subunit Composition of Complex I from Bovine Heart Mitochondria. Mol. Cell. Proteom. 2003, 2, 117-126.

3. Walker, J. E. The NADH:Ubiquinone Oxidoreductase (Complex I) of Respiratory Chains. Q. Rev. Biophys. 1992, 25, 253-324.
4. Carroll, J.; Fearnley, I. M.; Skehel, J. M.; Shannon, R. J.; Hirst, J.; Walker, J. E. Bovine Complex I is a Complex of 45 Different Subunits. J. Biol. Chem. 2006, 281, 32724-32727.

5. Galkin, A.; Brandt, U. Superoxide Radical Formation by Pure Complex I (NADH:Ubiquinone Oxidoreductase) from Yarrowia lipolytica. J. Biol. Chem. 2005, 280, 30129-30135.

6. Kudin, A. P.; Bimpong-Buta, N. Y.; Vielhaber, S.; Elger, C. E.; Kunz, W. S. Characterization of Superoxide-Producing Sites in Isolated Brain Mitochondria. J. Biol. Chem. 2004, 279, 4127-4135.

7. Turrens, J. F.; Boveris, A. Generation of Superoxide Anion by the NADH Dehydrogenase of Bovine Heart Mitochondria. Biochem. J. 1980 191, 421-427.

8. Costa, N. J.; Dahm, C. C.; Hurrell, F.; Taylor, E. R.; Murphy, M. P. Interactions of Mitochondrial Thiols with Nitric Oxide. Antioxid. Redox Signal. 2003, 5, 291-305.

9. Hurd, T. R.; Filipovska, A.; Costa, N. J.; Dahm, C. C.; Murphy, M. P.; Hurd, T. R.; Costa, N. J.; Dahm, C. C.; Beer, S. M.; Brown, S. E.; Filipovska, A.; Murphy, M. P. Disulphide Formation on Mitochondrial Protein Thiols Glutathionylation of Mitochondrial Proteins. Biochem. Soc. Trans. 2005, 33, 1390-1393.

10. Hurd, T. R.; Costa, N. J.; Dahm, C. C.; Beer, S. M.; Brown, S. E. Filipovska, A.; Murphy, M. P. Glutathionylation of Mitochondrial Proteins. Antioxid. Redox Signal. 2005, 7, 999-1010.

11. Beer, S. M.; Taylor, E. R.; Brown, S. E.; Dahm, C. C.; Costa, N. J.; Runswick, M. J.; Murphy, M. P. Glutaredoxin 2 Catalyzes the Reversible Oxidation and Glutathionylation of Mitochondrial Membrane Thiol Proteins: Implications for Mitochondrial Redox Regulation and Antioxidant DEFENSE. J. Biol. Chem. 2004, 279, 47939-47951.

12. Taylor, E. R.; Hurrell, F.; Shannon, R. J.; Lin, T. K.; Hirst, J.; Murphy, M. P. Reversible Glutathionylation of Complex I Increases Mitochondrial Superoxide Formation. J. Biol. Chem. 2003, 278, 19603-19610.

13. Beltran, B.; Orsi, A.; Clementi, E.; Moncada, S. Oxidative Stress and S-Nitrosylation of Proteins in Cells. Br. J. Pharmacol. 2000, 129, 953-960.

14. Clementi, E.; Brown, G. C.; Feelisch, M.; Moncada, S. Persistent Inhibition of Cell Respiration by Nitric Oxide: Crucial Role of S-Nitrosylation of Mitochondrial Complex I and Protective Action of Glutathione. Proc. Natl. Acad. Sci. U.S.A. 1998, 95, 7631-7636.

15. Chen, Y. R.; Chen, C. L.; Zhang, L.; Green-Church, K. B.; Zweier, J. L. Superoxide Generation from Mitochondrial NADH Dehydrogenase Induces Self-inactivation with Specific Protein Radical Formation. J. Biol. Chem. 2005, 280, 37339-37348.

16. Chen, C. L.; Zhang, L.; Yeh, A.; Chen, C. A.; Green-Church, K. B.; Zweier, J. L.; Chen, Y. R. Site-Specific S-Glutathiolation of Mitochondrial NADH Ubiquinone Reductase. Biochemistry 2007, 46, 5754-5765.

17. Sazanov, L. A.; Hinchliffe, P. Structure of the Hydrophilic Domain of Respiratory Complex I from Thermus thermophilus. Science 2006, 311, 1430-1436.

18. Fearnley, I. M.; Carroll, J.; Walker, J. E. Proteomic Analysis of the Subunit Composition of Complex I (NADH:Ubiquinone Oxidoreductase) from Bovine Heart Mitochondria. Methods Mol. Biol. 2007, 357, 103-125.

19. Carroll, J.; Fearnley, I. M.; Walker, J. E. Definition of the Mitochondria Proteome by Measurement of Molecular Masses of Membrane Proteins. Proc. Natl. Acad. Sci. U.S.A. 2006, 103, 16170-16175.

20. Chen, R.; Fearnley, I. M.; Peak-Chew, S. Y.; Walker, J. E. The Phosphorylation of Subunits of Complex I from Bovine Heart Mitochondria. J. Biol. Chem. 2004, 279, 26036-26045.

21. Xu, H.; Freitas, M. A. A Mass Accuracy Sensitive Probability Based Scoring Algorithm for Database Searching of Tandem Mass Spectrometry Data. BMC Bioinformatics 2007, 8:133.

22. Xu, H.; Zhang, L.; Freitas, M. A. Identification and Characterization of Disulfide Bonds in Proteins and Peptides from Tandem MS Data by Use of the MassMatrix MS/MS Search Engine. J. Proteome Res. 2008, 7, $138-144$.

23. Xu, H.; Freitas, M. A.; Monte Carlo. Simulation-Based Algorithms for Analysis of Shotgun Proteomic Data. I. Proteome Res. 2008, 7, 2605-2615.

24. Galante, Y. M.; Hatefi, Y. Purification and Molecular and Enzymic Properties of Mitochondrial NADH Dehydrogenase. Arch. Biochem. Biophys. 1979, 192, 559-568.

25. Vinogradov, A. D.; King, T. E. The Keilin-Hartree Heart Muscle Preparation. Methods Enzymol. 1979, 55, 118-127.

26. Redfearn, E. R.; Whittaker, P. A. The Determination of the OxidationReduction States of Ubiquinone (Coenzyme Q) in Rat-Liver Mitochondria. Biochim. Biophys. Acta 1966, 118, 413-418.

27. Hatefi, Y. Preparation and Properties of NADH: Ubiquinone Oxidoreductase (Complex I), EC 1.6.5.3. Methods Enzymol. 1978, 53, 11-14.

28. Duling, D. R. Simulation of Multiple Isotropic Spin-Trap EPR Spectra. J. Magn. Reson. B 1994, 104, 105-110.

29. Hansen, J. M.; Go, Y. M.; Jones, D. P. Nuclear and Mitochondrial Compartmentation of Oxidative Stress and Redox Signaling. Annu. Rev. Pharmacol. Toxicol. 2006, 46, 215-234.

30. Collins, E. S.; Wirmer, J.; Hirai, K.; Tachibana, H.; Segawa, S.; Dobson, C. M.; Schwalbe, H. Characterization of Disulfide-Bond Dynamics in Non-Native States of Lysozyme and its Disulfide Deletion Mutants by NMR. Chem. Biochem. 2005, 6, 1619-1627.

31. Haebel, P. W.; Wichman, S.; Goldstone, D.; Metcalf, P. Crystallization and Initial Crystallographic Analysis of the Disulfide bond Isomerase DsbC in Complex with the Alpha Domain of the Electron Transporter DsbD. J. Struct. Biol. 2001, 136, 162-166. 
32. Meier, S.; Haussinger, D.; Pokidysheva, E.; Bachinger, H. P.; Grzesiek, S. Determination of a High-precision NMR Structure of the Minicollagen Cysteine Rich Domain from Hydra and Characterization of Its Disulfide Bond Formation. FEBS Lett. 2004, 569, 112-116.

33. von Ossowski, L.; Tossavainen, H.; von Ossowski, I.; Cai, C.; Aitio, O.; Fredriksson, K.; Permi, P.; Annila, A.; Keinanen, K. Peptide Binding and NMR Analysis of the Interaction Between SAP97 PDZ2 and GluR-A: Potential Involvement of a Disulfide Bond. Biochemistry 2006, 45, 5567-5575.

34. Yen, T. Y.; Joshi, R. K.; Yan, H.; Seto, N. O.; Palcic, M. M.; Macher, B. A Characterization of Cysteine Residues and Disulfide Bonds in Proteins by Liquid Chromatography/Electrospray Ionization Tandem Mass Spectrometry. J. Mass Spectrom. 2000, 35, 990-1002.

35. Barbirz, S.; Jakob, U.; Glocker, M. O. Mass Spectrometry Unravels Disulfide Bond Formation as the Mechanism that Activates a Molecular Chaperone. J. Biol. Chem. 2000, 275, 18759-18766.

36. Fagerquist, C. K. Collision-Activated Cleavage of a Peptide/Antibiotic Disulfide Linkage: Possible Evidence for Intramolecular Disulfide Bond Rearrangement upon Collisional Activation. Rapid Commun. Mass Spectrom. 2004, 18, 685-700

37. John, H.; Forssmann, W. G. Determination of the Disulfide Bond Pattern of the Endogenous and Recombinant Angiogenesis Inhibitor Endostatin by Mass Spectrometry. Rapid Commun. Mass Spectrom. 2001, 15, 12221228 .

38. Krokhin, O. V.; Cheng, K.; Sousa, S. L.; Ens, W.; Standing, K. G.; Wilkins, J. A. Mass Spectrometric Based Mapping of the Disulfide Bonding Patterns of Integrin Alpha Chains. Biochemistry 2003, 42, 12950-12959.

39. Mundt, A. A.; Cuillel, M.; Forest, E.; Dupont, Y. Peptide Mapping and Disulfide Bond Analysis of the Cytoplasmic Region of an Intrinsic Membrane Protein by Mass Spectrometry. Anal. Biochem. 2001, 299, 147-157.

40. Tie, J. K.; Mutucumarana, V. P.; Straight, D. L.; Carrick, K. L.; Pope, R. M.; Stafford, D. W. Determination of Disulfide Bond Assignment of Human Vitamin K-Dependent $\gamma$-glutamyl Carboxylase by MatrixAssisted Laser Desorption/Ionization Time-of-Flight Mass Spectrometry. J. Biol. Chem. 2003, 278, 45468-45475.

41. Wolf, S. M.; Ferrari, R. P.; Traversa, S.; Biemann, K. Determination of the Carbohydrate Composition and the Disulfide Bond Linkages of Bovine Lactoperoxidase by Mass Spectrometry. J. Mass Spectrom. 2000, 35, 210-217.

42. Yen, T. Y.; Yan, H.; Macher, B. A. Characterizing Closely Spaced, Complex Disulfide Bond Patterns in Peptides and Proteins by Liquid
Chromatography/Electrospray Ionization Tandem Mass Spectrometry. J. Mass Spectrom. 2002, 37, 15-30.

43. Zeng, R.; Xu, Q.; Shao, X. X.; Wang, K. Y.; Xia, Q. C. Determination of the Disulfide Bond Pattern of a Novel C-Type Lectin from Snake Venom by Mass Spectrometry. Rapid Commun. Mass Spectrom. 2001, 15, 2213 2220 .

44. Zubarev, R. A. Electron-Capture Dissociation Tandem Mass Spectrometry. Curr. Opin. Biotechnol. 2004, 15, 12-16.

45. Debski, J.; Wyslouch-Cieszynska, A.; Dadlez, M.; Grzelak, K.; Kludkiewicz, B.; Kolodziejczyk, R.; Lalik, A.; Ozyhar, A.; Kochman, M. Positions of Disulfide Bonds and N-Glycosylation Site in Juvenile Hormone Binding Protein. Arch. Biochem. Biophys. 2004, 421, 260-266.

46. Jones, M. D.; Hunt, J.; Liu, J. L.; Patterson, S. D.; Kohno, T.; Lu, H. S Determination of Tumor Necrosis Factor Binding Protein Disulfide Structure: Deviation of the Fourth Domain Structure from the TNFR/ NGFR Family Cysteine-Rich Region Signature. Biochemistry 1997, 36, 14914-14923.

47. Jones, M. D.; Patterson, S. D.; Lu, H. S. Determination of Disulfide Bonds in Highly Bridged Disulfide-Linked Peptides by Matrix-Assisted Laser Desorption/Ionization Mass Spectrometry with Post-Source Decay. Anal. Chem. 1998, 70, 136-143.

48. Cole, A. R.; Hall, N. E.; Treutlein, H. R.; Eddes, J. S.; Reid, G. E.; Moritz, R. L.; Simpson, R. J. Disulfide Bond Structure and N-Glycosylation Sites of the Extracellular Domain of the Human Interleukin-6 Receptor. J. Biol. Chem. 1999, 274, 7207-7215.

49. Merewether, L. A.; Le, J.; Jones, M. D.; Lee, R.; Shimamoto, G.; Lu, H. S. Development of Disulfide Peptide Mapping and Determination of Disulfide Structure of Recombinant Human Osteoprotegerin Chimera Produced in Escherichia coli. Arch. Biochem. Biophys. 2000, 375, 101-110.

50. Pitt, J. J.; Da Silva, E.; Gorman, J. J. Determination of the Disulfide Bond Arrangement of Newcastle Disease Virus Hemagglutinin neuraminidase. Correlation with a $\beta$-Sheet Propeller Structural Fold Predicted for Paramyxoviridae Attachment Proteins. J. Biol. Chem. 2000, 275, 6469 6478

51. Wallis, T. P.; Huang, C. Y.; Nimkar, S. B.; Young, P. R.; Gorman, J. J. Determination of the Disulfide Bond Arrangement of Dengue Virus NS1 Pprotein. J. Biol. Chem. 2004, 279, 20729-20741.

52. Sali, A.; Blundell, T. L. Comparative Protein Modeling by Satisfaction of Spatial Restraints. J. Mol. Biol. 1993, 234, 779-815.

53. Seeger, M. A.; von Ballmoos, C.; Eicher, T.; Brandstatter, L.; Verrey, F.; Diederichs, K.; Pos, K. M. Engineered Disulfide Bonds Support the Functional Rotation Mechanism of Multidrug Efflux Pump AcrB. Nat. Struct. Mol. Biol. 2008, 15, 199-205. 